\title{
Does Learning Opportunity Matters in Employee Retention?
}

\author{
Maryam Tijjani Abba ${ }^{1, *}$, Munir Babanmairam ${ }^{2}$ \\ ${ }^{1}$ Department of Marketing, Federal Polytechnic Bauchi, PMB 0231, Bauchi, Bauchi State, Nigeria. \\ ${ }^{2}$ Department of Business Administration, Faculty of Management Sciences, University of Jos, Jos, Plateau State, Nigeria.
}

How to cite this paper: Maryam Tijjani Abba, Munir Babanmairam. (2021) Does Learning Opportunity Matters in Employee Retention? Journal of Humanities, Arts and Social Science, 5(2), 231-248.

DOI: $10.26855 /$ jhass.2021.07.007

Received: August 3, 2021

Accepted: August 26, 2021

Published: September 7, 2021

${ }^{*}$ Corresponding author: Maryam Tijjani Abba, Department of Marketing, Federal Polytechnic Bauchi, PMB 0231,

Bauchi, Bauchi State, Nigeria.

Email: tijjaniabbahmaryam@gmail.com

\begin{abstract}
The study examined the relationship between learning opportunity and employee retention in some selected banks within Bauchi metropolis. Banks in Nigeria are faced with myriad of problems related to learning opportunity and employee retention. For instance, the inability to send employees for further studies/learning opportunity to manage and support their carrier successfully will not help in retaining valuable employees. In a style of a quantitative research, descriptive-casual survey method was adopted. Data were collected from the administration of questionnaire and were analyzed using multiple regression analysis. The findings show learning opportunity has a negative relationship with employees' retention. This means that the less learning opportunity, the more likely the employees are willing to stay and retained. This means that when employees are not given the opportunity to acquire additional educational knowledge, the less likely are the employees retained. As part of the conclusion, the result shows the P-value of learning opportunity is greater than the 0.05 level of significance. This implies that learning opportunity has no significant effect on employees' retention. The research recommends that a dissatisfied employee cannot work effectively to achieve the organizational goals. Therefore, banks should value their employees as assets and not liabilities. Again, banks in Nigeria and Bauchi in particular should provide learning opportunity for staff to achieve adequate productivity, they should also discourage outsourcing in their system. This is because the contract or outsourced staff provides cheap labour which will affect the level of trust and trust when undermined could create room for dishonest practices and fraud which inevitably leads to bank collapse.
\end{abstract}

\section{Keywords}

Employee, Employee Motivation, Employee Retention, Herzberg two-factor theory, learning Opportunity

\section{Introduction}

Banking sub-sector of the financial sector of any nation can be described as the driving engine of the nation's economy to the extent that if the banking industry fails, the economy fails, and vice versa. Thus, the performance of banks goes a long way in determining the intermediation process of the economy (Ojo, 1994 cited in Olalere \& Adenugba, 2013). This performance can be measured in terms of earnings per share, profitability index, returns on equity (ROE), and the rest of it. The relevance of the banks performance in the economic status of a nation provides the reason why the Nigerian government has always placed a great emphasis on improving the effectiveness of this industry over the years. The integration of the world economies into a global village in the face of ever-increasing 
ICT coupled with the challenges posed by the depressed economy and the increased competition from other nations' banks necessitated the need for a more productive human resource.

Due to the dynamic and competitive nature of the banking environment, an innovative human resource development practices have to focus on equipping employees with new and diverse skills, and also to ensure flexibility of employees so as to be able to respond to the current changes. Human resource development practices need to consciously turn around issues that not only enhance job security but make the employee satisfied on the job with increased job security and satisfaction (Barrows \& Wesson, 2000). This derives from the fact that the best asset in an organization are the people, and not just people, skilled and competent people who need to be managed effectively to ensure job satisfaction and retention. However, the situation in the Nigerian banking sector has potentials for high attrition rate due to poor human resource development practices and employee retention: evidence from the Nigerian banking industry such as lack of job security and satisfaction occasioned by adjustments in the industry abound. There have been many justifiable factors that affect retention, such as company image, learning opportunities, performance recognition and rewards, job security, fair pay, training and development and working conditions (Abraham \& Medoff, 1984). The retention policy involves strategies put in place to make employees comfortable at work so as to improve their job satisfaction to enable the workforce remains in that organization (Abraham \& Medoff, 1985). Any other practice otherwise would reduce the satisfaction of employees.

The importance of human resources in an organization can be well perceived in the fact that factors of production including land and capital cannot translate themselves into economic outputs unless with the coordinated efforts of men. This view is shared by Psacharopoulos and Woodhall (1997) who assert that human resources constitute the ultimate basis of the wealth of nations; capital and national resources are passive factors of production but human beings are the active agencies who accumulate capital, exploit national resources, build social, economic and political organization and carry on national development.

Human Resource Development is seen as a process of acquiring and increasing the number of persons who have the skills, education and experience which are critical for the economic growth of the country (Harbison, 1962). In addition, a discourse on human resource development practices in the banking industry is about investing in improving the skills, innovation and technical capability of the workforce with the target of improved productivity and employee retention. It can be arguably said that the concept of training and development practices not restricted to workers alone but extends to the employers because they too need to sharpen their innate resources for more efficiency and effectiveness in the management of physical and other human resources.

Today's economic operations, especially of banks, are knowledge-based, and for a bank to meet the challenge of dynamism of business and the ever-growing global interconnectivity of banking operations, great attention should be paid to training and development. Meeting the N25billion recapitalization by banks, construction of captivating structures, and acquisition of modern physical assets cannot, in themselves, translate to operational success, unless with the competences, skills and creativity of the available human resources. This of course is an x-ray of the significance of human resource development practices.

The main ingredients that make up the qualities of human resource development practices as identified by various authors and researchers. These include; quality education, training and development, fair pay, good working condition and good health (Oluwatobi \& Ogunrinola, 2011; Odusola, 1998; Barro \& Sala-i-Martin, 1995; Becker, 1993; Okadara, 1978). Becker's (1993) perspective for instance, modern economists seem to concur that education and health care are the key to improving human resource and ultimately increasing the economic outputs of the nation. Atagana (2011), however, widens the scope of human resource development to include investment in education, training, health as well as investment in all social services which influence man's productive capacities, especially transport facilities and housing. It is so considered for the fact that efficient management of the earlier mentioned resource elements cited in this work will go a long way to enhance economic growth of a country.

The paper, here, therefore, investigates the effect of learning opportunity on employee retention in banks within Bauchi metropolis. In order to achieve these research objectives, the paper exhaustively reviews literatures on learning opportunity and employee retention.

\subsection{Statement of Problem}

Banks in Nigeria are faced with myriad of problems related to learning opportunity and employee retention. One of the problems include the inability to send employees for further studies/learning opportunity to manage and support their carrier successfully will not help in retaining valuable employees (Sherman et al., 1998). 
This study seeks to examine the effects of learning opportunity and reward on employee retention.

\subsection{Research Question}

The question formulated for these research states whether if learning opportunity has any significance on employee retention in Bauchi metropolis Banks?

\subsection{Objective of the Study}

The study is aimed to examine the relation between learning opportunities and employee retention in Bauchi metropolis Banks.

\subsection{Hypothesis}

$\mathbf{H}_{\mathbf{0}}$ : Learning opportunity has no significant effect employee retention in Bauchi metropolis Banks.

$\mathbf{H}_{\mathbf{1}}$ : Learning opportunity has a significant effecton employee retention in Bauchi metropolis Banks.

\section{Literature Review}

\subsection{Conceptual Framework}

\subsubsection{Employee Retention}

Employee retention can be defined as the policies and practices organizations use to avoid precious employees from quitting their jobs. However, Ben-Bakr, Al-Shammari, Jefri and Prasad (1994) argued that organizations can avoid business instability when talented employees are retained. Retention can be seen as the ability to hold onto those employees you want to keep, for longer than your competitors (Johnson, 2002, cited in Shaibu, Noor, Tirmizi \& Bashir, 2009). Again, Denton (2000) puts forward the view about employee retention that employees who are contented and satisfied with their jobs are more devoted towards their job and always put their effort to progress their organizational customers' satisfaction.

Researchers such as Taplin, Winterton, and Winterton (2005), Amadasu (2003) and Gberebie (2003) have established in their studies that, employees will surely stay and work for the flourishing and accomplishment of organizational goals if suitable employee retention strategies are adopted and implemented by organizations. In addition, Action and Golden (2003) state that retention of employees is not only important but retention of valued skills is more important. According to the researchers, human resource department plays the dynamic role for retention of employees. Kossivi and Kalgora (2016) attempted to study the various factors for retention from the findings of various previous research studies and brought some factors such as opportunity for development, work-life balance, compensation, style of leadership of the management, work environment, autonomy, training and development, social support, etc.

Freyermuth (2007) commented that retention starts with the recruiting of correct individuals and continues with practicing program to keep them engaged and committed to the organization. According to him, it is considered as multifaceted component of an organization resource policies.

Baker (2006) said that employee retention is very important as because of the fact that hiring new employees are far complicated as well as costlier than to remain with the present employees in the organization.

However, Olowu and Adamolekum (2005), stated that because of the need for effective and efficient delivery of goods and services by organizations in public or private sector, it is becoming more essential to secure and manage competent human resource as the most valuable resource of any organization.

Gberebie (2008) has assured that employee retention implementation strategies are very important. In addition, employee retention strategies refer to the strategy and means and a set of decision making behaviour put formulated by organizations to retain their competent workforce for performance.

\subsubsection{Learning Opportunity}

Learning opportunity in an organization should be viewed as a very dynamic process that attempts to meet the needs of managers, subordinates and organizations. It is the responsibility of managers to encourage employees to take responsibility for their own careers, offering continuous assistance in the form of feedback or individual performance and making available information from the company about the organization, learning opportunities, positions and vacancies that might be of interest to the employees (Zandy et al., 1986). It cannot be denied that in career development process, the organization must supply adequate information about its mission, policies, and support for self-assessment, training and development. It is important to note that significant career growth can occur when 
individual contribution combines with organization opportunity. Increase in skills and the opportunity to manage their career successfully helps to retain valuable employees (Sherman et al., 1998).

A study was carried out by Ming Chuang University in Taiwan on R\&D personnel to explore the career needs. The study proposes the concept of the gap between career development programs and career needs, and its subsequent effect on job satisfaction and turnover intention. A set of questionnaires were completed by $367 \mathrm{R} \& \mathrm{D}$ personnel. The results reveal that $R \& D$ personnel have very diverse career needs at various stages of their career. Depending on which stage of their career they have reached, the larger the gap, the higher the levels of both turnover intentions and job dissatisfaction (Tser et al., 2004). In another study conducted by scholars on the nursing industry in the USA, the subject was to examine the relationships between work satisfaction from career development, stress, age, cohesion, work schedule, and anticipated turnover in an academic medical center.

Questionnaires were used to get feedback from staff of the 908 Bed University hospital and results revealed that job satisfaction derived from an established career development program and putting people in the right job and responsibility actually reduce stress because of better cohesion and work schedule management. This in turn has significant relation to staff retention and negate turnover intentions (Shader et al., 2001).

Similarly, a study on Information System Auditors in the US revealed that professional growth related to career progression was related to turnover intentions and consequently the companies were advised to have regular career advancement opportunities and professional growth for their staff in a bid to retain them (Muliawan, 2009). As learning opportunity involves an organized, formalized, planned effort to achieve a balance between an individual's career needs and the organization's workforce requirements, it is important for an organization commitment in the program (Lips \& Hall, 2007). To highlight these theories further, a look at another research which was conducted by the University of Haifa of Israel on the turnover intentions of welfare workers is necessary. The predictors were commitment and job satisfaction. It was verified that welfare organizations serve as an example of the importance of job involvement and organizational commitment to promote professional and effective work and such goals are very important for employees' career commitment and job satisfaction. A total of 330 respondents were involved and the result revealed that career commitment and job satisfaction have significant effect on reversing turnover intentions (Anna, 2008). Furthermore, a study on 442 design engineers, revealed that the existence of career advancement within the organization actually lower turnover intentions (Barbara, 2012). Similar study by University of Technology MARA, Malaysia, on 380 employees from 5-star hotels revealed that besides having good HR practices, other predictors such as career advancement program is essential to negate turnover intentions (Helmi, 2006).

\subsection{Theoritical Framework}

\subsubsection{Herzberg Two-Factor Theory}

One of the earliest researches in the area of employee retention that affected motivation was Frederick Herzberg work (Herzberg, Mausner, \& Synderman, 1959). Herzberg and his associates began their initial work on factors affecting work motivation in the mid-1950s. Their first effort entitled a "thorough review of existing research" to that date on the subject (Herzberg et al., 1959). Based on the review, Herzberg carried out his now famous survey of 200 accountants and engineers from whom he derived the initial frame work for his theory of motivation. The theory, as well as the supporting data was first published in 1959 (Herzberg et al., 1959) and was subsequently amplified and developed in a later book (Herzberg, 1966). Based on his survey, Herzberg discovered that employees tended to describe satisfying experiences in terms of factors that were intrinsic to the content of the job itself. These factors were called "motivators" and concluded such variables as achievement, recognition, the work itself, responsibility, advancement and personal growth. Conversely, dissatisfying experiences, called "hygiene" factors, largely resulted from extrinsic, non-job-related factors, such as company policies and administration, salary, coworker relations, and supervisory styles, job security, personal life, work condition and status (Steers \& Porter, 1983). Herzberg argued based on these results that eliminating the causes of dissatisfaction (through hygiene factors) would not result in a state of satisfaction. Instead, it would result in a neutral state. Satisfaction (and motivation) would occur only as a result of the use of motivators (Herzberg, 1966).

The implications of this theory of employee motivation are clear: motivation can be increased through basic changes in the nature of an employee's job, that is, through job enrichment (Steers \& Porter, 1983). Thus, jobs should be redesigned to allow for increased challenge and responsibility, opportunities for advancement, and personal growth, and recognition.

According to Herzberg (1966), the "factors leading to job satisfaction are separate and distinct from those, that lead 
to job dissatisfaction”. Therefore, managers who seek to eliminate factors that create job dissatisfaction can bring about peace, but not necessarily motivation. They will be placating their work force rather than motivating them to stay for life (Robins, 1993). Kreitner and kinicki (1998) highlight one of Herzberg's findings, where managers rather than giving employees additional tasks of similar difficulty (horizontal loading), "vertically loading" consists of giving workers more responsibility. This is where employees take on tasks normally performed by their supervisors.

In essence, there are more to a manager's role in motivating employees other than compensation, good working conditions, and similar factors. Herzberg argued that for an employee to be truly motivated, the employee's job has to be fully enriched where the employee has the opportunity for achievement and recognition, stimulation, responsibility, and advancement.

Although, Herzberg's theory was generally accepted, there are some criticisms that it applies least to people with largely unskilled jobs or those whose work are interesting, repetitive, monotonous and limited in scope. He was also accused of assuming a correlation between satisfaction and productivity through his research stressed satisfaction and ignored productivity. Recent research indicates that employee satisfaction does not necessarily contribute directly to productivity. Satisfaction may be viewed as a passive attribute, while more proactive measures such as motivation levels are viewed as more closely linked to behavioural changes and performance (Hayday, 2003).

As many as behavioural scientists agree with Herzberg that employees are well motivated when the motivator factors are achieved. Other schools of thought share different opinion. Some behavioural scientists also argue that there is more to motivating employees and getting them satisfied than just the motivator factors enumerated Herzberg.

On another interesting note, some behavioural scientists have sought to invalidate Frederick Herzberg's, motivation-hygiene claiming it lacks empirical support. One of such scientist is king (2005). In his book; 'clarification and evaluation of the two-factor theory', which appeared in the psychological bulletin, he sought to explicate and evaluate five distinct versions of the two-factor theory of job satisfaction. He concluded that two of these versions are invalid, as they are not supported by any empirical studies.

A criticism leveled against Herzberg's theory suggesting that Herzberg's original formulation of the model may have been a methodological artifact. It was further explained that, the theory does not consider individual differences, conversely predicting all employees will react in an identical manner to changes in motivating-hygiene factors. Furthermore, concern was raised, that Herzberg's theory did not specify how motivation and hygiene factors are to be measured (Hackman \& Oldman, 1976).

While some behavioural scientist raised issues with the critical incident technique used by Herzberg in collecting data as appropriate, others like Bellot and Tutor (1990) had problems with the type of employees used. According to a research study conducted by Tutor in 1986 with Tennessee Career Ladder Program (TCLP), they concluded that not all employees are motivated by Herzberg's 'motivator needs' and that, teachers especially were more motivated by hygiene needs like money. They criticized Herzberg for using employees from only industrial sector.

For the purpose of this study, the Herzberg two-factor theory has been applied. The reason being that most of the variables used in the work are embedded in Herzbergs' theory. Therefore, banks should choose any of the factors that best suit an employee in other to reduce the rate of employee turnover in the banking industry.

\subsection{Empirical Review}

\subsubsection{Learning Opportunity and Employee Retention}

One of the issues facing organizations today is to retain their employees (Allen, 2008). And Learning opportunity is one of the main human resource characteristics that provide the opportunity for employees to continuously be a part in the diverse activities in the organization that develops employees (SHRM, 2012). Learning opportunity activities includes succession planning (Cedefop, 2008), talent management (SHRM, 2012), leadership development (Day, 2007), structured career management and self-assessment (Right Management, 2009). The outcome of succession planning was development for further growth, work shadowing, job rotation within the organization and promotion leading to employee retention (Cedefop, 2008). Similarly structured career management improves the employee's organizational commitment and behaviour (Right Management, 2009) resulting further employee retention. Also self-assessment helps to establish commitment to perform better in the organization and enriches the skills of functioning in the work place (Right Management, 2009).

\section{Methodology}

The research examines the impact of learning opportunity on employee retention in some selected banks in Bauchi. 
The research designs used for this study is the survey method (Descriptive-Casual survey method). Questionnaire was used in collecting data from the banks while the top and middle level staff of the banks formed the population of the study. The primary data is basically from the administration of questionnaire. This is conducted with the focus population of the research work, that is, the top and middle level staff in Banks within Bauchi metropolis.

In order to examine the impact of job security on Employee Retention in some selected banks within Bauchi metropolis, the following Logit model (Simple regression model) stated below was used to test the hypothesis:

$$
E R_{i}=\beta_{0}+\beta_{1} L O_{i}+U_{i}
$$

where

$\mathrm{ER}=$ Employee retention

LO = Learning Opportunity

$\mathrm{U}=$ error term

\section{Analysis and Results}

Table 1. Reliability Test Result

\begin{tabular}{cccccc}
\hline S/N & Questionnaire & Cronbach Alpha Reliability Result & Number of Items & Remark \\
\hline & Questionnaire Instrument & 0.770 & 5 & Very Reliable \\
\hline
\end{tabular}

Source: SPSS 22.0 Output

Table 1 shows the result of the reliability test of the research instrument. The result shows that the instrument is very reliable.

\subsection{Descriptive Statistics}

Table 2. Learning opportunity and employee retention

\begin{tabular}{|c|c|c|c|c|}
\hline $\mathrm{S} / \mathrm{N}$ & Variable & Scale $(x)$ & Frequency $(f)$ & $\%$ \\
\hline \multirow{7}{*}{ a. } & Learning opportunities retain & & & \\
\hline & Strongly Disagree & 1 & 9 & 4.6 \\
\hline & Disagree & 2 & 11 & 5.6 \\
\hline & Undecided & 3 & 48 & 24.4 \\
\hline & Agree & 4 & 88 & 44.7 \\
\hline & Strongly Agree & 5 & 40 & 20.3 \\
\hline & Total & & 196 & 100 \\
\hline \multirow{7}{*}{ b. } & Academic opportunities makes employees u & & & \\
\hline & Strongly Disagree & 1 & 3 & 1.5 \\
\hline & Disagree & 2 & 14 & 7.1 \\
\hline & Undecided & 3 & 43 & 21.8 \\
\hline & Agree & 4 & 102 & 51.8 \\
\hline & Strongly Agree & 5 & 33 & 16.8 \\
\hline & Total & & 195 & 100 \\
\hline
\end{tabular}

Sources: Survey Data (2020)

The frequency result in Table 2 seeks to find out the extent learning opportunity influences employees' retention. It shows that majority of the respondents agree (88 or $44.7 \%$ ) and agree that academic opportunities make employees uninterested in their jobs with frequency of (102 or 51.8\%). This shows that learning opportunities influence employees' retention. 


\subsection{Model Summary}

Table 3. Model Summary

\begin{tabular}{cccccc}
\hline Model & $\mathrm{R}$ & R Square & Adjusted R Square & Std. Error of the Estimate & Durbin-Watson \\
\hline 1 & $0.265^{\mathrm{a}}$ & 0.070 & 0.039 & 0.51991 & 1.976 \\
\hline
\end{tabular}

Table 3 shows the value of the correlation coefficient and the R-squared. The correlation value shows the effect of the relationship between the dependent and independent variables. The value of the $R, 0.265$ which is $26.5 \%$ shows that there is weak relationship between the dependent and independent variables. The value of the coefficient of determination $\mathrm{R}^{2}, 0.070$, which is $7 \%$ indicated that the fair pay contributes to employee retention is only $7 \%$. Since the value of Durbin-Watson is approximately 2, the result indicated that there is no autocorrelation.

Table 4. ANOVA

\begin{tabular}{ccccccc}
\hline & Model & Sum of Squares & Df & Mean Square & F & Sig. \\
\hline \multirow{3}{*}{1} & Regression & 3.748 & 7 & 0.535 & 2.044 & $0.052^{\mathrm{b}}$ \\
& Residual & 49.516 & 189 & 0.262 & & \\
& Total & 53.264 & 196 & & & \\
\hline
\end{tabular}

Table 4 shows the result of the F-test with a value of 2.044 and p-value of 0.052 . This shows that there is a strong linear dependency existing among the variables, since the P-value is less than 0.10 . It indicates that the regression model is a good fit for determining the effects of job security on employees' retention among banks in Bauchi Metropolis.

\subsection{Regression Result}

Table 5. Regression result

\begin{tabular}{|c|c|c|c|c|c|c|c|c|}
\hline & \multirow{2}{*}{ Model } & \multicolumn{2}{|c|}{ Unstandardized Coefficients } & \multirow{2}{*}{$\begin{array}{c}\text { Standardized Coefficients } \\
\text { Beta }\end{array}$} & \multirow{2}{*}{$\mathrm{T}$} & \multirow{2}{*}{ Sig. } & \multicolumn{2}{|c|}{ Collinearity Statistics } \\
\hline & & B & Std. Error & & & & Tolerance & VIF \\
\hline \multirow{2}{*}{1} & (Constant) & 2.301 & 0.418 & & 5.510 & 0.000 & & \\
\hline & LO & -0.002 & 0.086 & -0.003 & -0.026 & 0.979 & 0.549 & 1.820 \\
\hline
\end{tabular}

a. Dependent Variable: ER

Learning opportunity (LO) with coefficient value of $(\beta=-0.002)$, has a negative relationship with employees' retention. This means that the less the learning opportunity, the more likely the employees' are willing to stay and retained. This means that when employees are not given the opportunity to acquire additional educational knowledge, the less likely are the employees retained. The P-value of the learning opportunity is greater than the 0.05 level of significance. This implies that learning opportunity has no significant effect on employees' retention.

\subsection{Test of Hypothesis}

$\mathbf{H}_{\mathbf{0}}$ : Learning opportunity has no significant impact on employee retention in Bauchi metropolis Banks.

$\mathbf{H}_{1}$ : Learning opportunity has a significant impact on employee retention in Bauchi metropolis Banks.

Decision Rule: Reject Ho if $P<0.05$

Accept Ho if $P>0.05$

The decision rule is that if the p-value is less than the level of significance of 0.05 , the null hypothesis will be rejected while the alternate hypothesis is accepted. But if the p-value is greater than the level of 0.05 , accept the null hypothesis and reject the alternate.

Given that the P-value of the job security is (0.979) is greater than the 0.05 level of significance. Therefore, accept the null hypothesis and reject the alternate concluding that learning opportunity has no significant impact on employee retention in Bauchi metropolis Banks.

\section{Discussion of Findings}

From the result seen, the P-value of learning opportunity is greater than the 0.05 level of significance. This implies that learning opportunity has no significant effect on employees' retention. This is not in line with the findings of 
Sherman et al. (1998) who stated that significant career growth can occur when individual contribution is combined with organization opportunity. Increase in skills and the opportunity to manage their career successfully helps to retained valued employees.

\subsection{Conclusion}

The study concluded that learning opportunity has a negative percentage of -3\% which signifies that it has no any impact on employee retention. The following recommendations are made based on the finding of this study.

\subsection{Recommendations}

The following recommendations are made based on the findings of this study:

The importance of learning opportunity in an organization cannot be over emphasized. This is because employees are the engine of the system (organization) that keeps it running.

1) The result shows that learning opportunity is insignificant to employee retention. Therefore, banks in Nigeria and Bauchi in particular should provide learning opportunity for staff to achieve adequate productivity.

2) Successful banking operation is predicated on employees that are motivated, energetic and focused. A dissatisfied employee cannot work effectively to achieve the organizational goals. Therefore, banks should value their employees as assets and not liabilities. They should embark on paying valued salaries and provide good training facilities for effective performance.

3) The study recommended that; banks should discourage outsourcing in their system. The use of contract and outsourcing staff for the purpose of building a strong trust mechanism. The contract or outsourced staff provides cheap labour. Cheap labour could affect the level of trust and trust when undermined could create room for dishonest practices and fraud which inevitably leads to bank collapse.

\section{References}

Abegglen, J. C. (1958). The Japanese Factory. Aspects of its Social Organization Free Press. Glencoe. IL. Accounting Review. Vol. 53, No. 2, pp. 336-359.

Abraham, K. and Medoff, J. L. (1984). "Length of Service and Layoffs in Union and Non-union Work groups”. Industrial and Labor Relations Review, 38(1): 87-97.

Abraham, K. and Medoff, J. L. (1985). "Length of Service and Promotions in Union and Non-union Work Groups”. Industrial and Labor Relations Review, 38(3): 408-420.

Action, T. and Golden, W. (2003). "Training the knowledge worker: A descriptive study of training practices in Irish software companies”. Journal. Eur. Ind. Train, 27(4): 137-146.

Acton, T. and Golden, W. (2003). Training the Knowledge Worker: A Descriptive Study of Training Practices in Irish Software Companies. Journal of European Industrial Training, Vol. 27, No. 4, pp. 137-146.

Agarwal, N. C. (1998). Reward Systems: Emerging Trends and Issues. Canadian Psychology, 39(1), 60-70.

Ahmad, O. and Schroeder, R. G. (2003). The Impact of Human Resource Management Practices on attraction of African American Applicants. Personnel Psychology, Vol. 52, No. 2, pp. 425-426.

Alan, K. M. A., Altman, Y., and Roussel, J. (2008). Employee Training Needs and Perceived Value of Training in the Pearl River Delta of China: A Human Capital Development Approach. Journal of European Industrial Training, 32(1), 19-31.

Alexander, K. (1996). The Value of an Education. MA: Simon \& Schuster.

Allen, D. G. (2006). Do organization socialization tactics influence newcomer embeddedness and turnover? Journal of Management, 32, 237-256.

Allen, R. and Helms, M. (2002). "Employee perceptions of relationships between strategy rewards and organizational performance”. Journal of Business Strategies, Vol. 19, No. 2, pp. 115-139.

Allen, T. D. (2001). Family-Supportive Work Environments: The Role of Organizational Perceptions. Journal of Vocational Behavior, 58(3): 414-435.

Amadasu, D. E. (2003). Personnel and the Nigerian Management Crisis: Ajaokuta Iron and Steel Mill Examined. Abuja Management. Rev., Vol. 1, No. 4. 
Andreassen, T. W. and Lanseng, E. (1997). “The principal's and agents' contribution to customer loyalty within an integrated service distribution channel: An external perspective”. European Journal of Marketing, Vol. 31, No.7, pp. 487-503.

Andreassen, T. W. and Lindestad, B. (1998). "Customer loyalty and complex services: The impact of corporate image on quality, customer satisfaction and loyalty for customers with varying degrees of service expertise”. International Journal of Service Industry Management, Vol. 9, No.1, pp. 7-23.

Appelbaum, E., Berg, P., and Kalleberg, A. (2000). Balancing work and family: effects of high performance work systems and high-commitment workplaces. Report to the US Department of Labour, Washington, DC.

Armstrong, M. (2000). “Understanding training”. Human Resource Management Practice. $8^{\text {th }}$ Edition. Kogan page limited, London. P. 543

Arnold, H. J. and Feldman, D. C. (1982). A Multivariate Analysis of the Determinants of Job Turnovet, Journal of Applied Psychology, Vol. 67, pp. 350-360.

Arthur, J. (1994). Effects of Human Resource Systems on Manufacturing Performance and Turnover. Academy of Management Journal, Vol. 37, pp. 670-687.

Atagana, S. (2011). Human Capital Development and Economic Growth in Nigeria. Available at http://www.career_tech_ed/2009/12/human-capital-development-theory.html.Retrieved 15th April, 2014.

Available at www.personneltoday.com/article/2003/06/10/19275/staff-commitment-is-the-keyto an (assessed 10 march, 2011).

Baker, E. (2006). The Human Factor, CIO Insight, Vol. 73, pp. 40-50.

Banker, R. D., Lee, S. Y., Potter, G., and Srinivasan, D. (2001). An Empirical Analysis of Continuing Improvements following the Implementation of a Performance-based Compensation Plan. Journal of Accounting and Economics, Vol. 30, No. 3, pp. 315-350.

Baron, J. N. and Hannan, M. T. (2002). Organizational blueprints for success in high-tech start-ups: Lessons from the Stanford project on emerging companies. California Management Review, 44(3): 8-36.

Baron, J. N. and Kreps, D. M. (1999). Strategic Human Resources: Frameworks for General Managers. New York: John Wiley \& Sons.

Barringer, B. R., Jones, F. F., \& Neubaum, D. O. (2005). A quantitative content analysis of the characteristics of rapid-growth firms and their founders. J. Bus. Vent., 20: 663-687.

Barro, R. and Sala-i-Martin, X. (1995). Economic Growth. New York: McGraw Hill.

Barrows, D. and Wesson, T. (2000). "A Comparative Analysis of Job Satisfaction Among public and private sector professionals”. The Innovation Journal, 5(1). http://www.innovation.cc/volume\&issues/vol5_iss1.htm.

Beach, M. J. (2009). A Critique of Human Capital Formation in the U.S. and the Economic Returns to Sub-Baccalaureate Credentials. Educational Studies: A Journal of the American Educational Studies, 45(1), 24-38.

Becker, G. S. (1993). Human Capital: A Theoretical and Empirical Analysis with Special Reference to Education (3rd ed.).

Begley, T. M., Lee, C., Fang, and Li, J. (2002). Power distance as a moderator of relationship justice and employee outcomes in a sample of Chinese employees, J. Manage. Phys., 17(8). Behaviour and Human Performance, vol. 16, pp. 250-79.

Ben-Bakr, K. A., Al-Shammari, I. S., Jefri A. O., and Prasad, J. N. (1994). Organizational Commitment, Satisfaction and Turnover in Saudi Organizations: A Predictive Study. Journal of Socio-Economics, Vol. 23, No. 4, pp. 449-456.

Bennett, N., Blume, T. C., Long, R. G., \& Roman, P. M. (1993). A firm-level analysis of employee attrition. Group and Organization Management, 18(4): 482-99.

Bitner, M. J. (1990). "Evaluating service encounters: the effects of physical surroundings and employee responses". Journal of Marketing, Vol. 54, No. 2, (April), pp. 69-82.

Bitner, M. J. (1991). "The evolution of the services marketing mix and its relationship to service quality”, in Brown, S., Gummesson, E., Edvardsson, B., and Gustavsson, B., Service Quality: A Multidisciplinary and Multinational Perspective, Lexington Books, New York, NY, pp. 23-37.

Blau, P. (1964). Exchange and Power in Social Life. New York: John Wiley \& Sons.

Bloemer, J. and Odekerken-Schro"der, G. (2006). The role of employee relationship proneness in creating employee 
loyalty. Int. J. Bank Mark., 24(4): 252-264.

Bravo, R., Montaner, T., and Pina, J. M. (2009). The role of bank image for customers versus.

Brill, M., Weidemann, S., Olsen, J., Keable, E., and BOSTI. (2001). "Disproving widespread myths about workplace design.” Research report.

Caligiuri, P., Lepak, D., and Bonache, J. (2010). Global Dimensions of Human Resources Management: Managing the Global Workforce. Hoboken, NJ: John Wiley \& Sons, Inc.

Cappelli, P. (2000). A Market-Driven Approach to Retaining Talent. Harvard Business Review, Vol. 78, No. 1, pp. 103-111.

CBN Financial Stability Report. (Jan 2009-June 2010). http://www.cenbank.org/out/2010/publications/bsd/financial\% 20stability\%20final\%20to\%20printer\%20-\%2015102010.pdf.

Cerio, J. and Merino-Diaz, D. (2003). Quality management practices and operational performance: empirical evidence for Spanish industry. Int. J. Product. Res., 41(12): 2763-2786. Chicago: University of Chicago Press.

Cho, S., Woods, R., Jang, S., and Erdem, M. (2006). "Measuring the impact of human resource management practices on hospitality firms’ performances”. Int. 1 J. Hospitalit. Manag., 25(2): 262-77.

Chung, B. G. and Schneider, B. (2002). "Serving multiple masters: role conflict experienced by service employees", Journal of Services Marketing, Vol. 16, No. 1, pp. 70-87.

Cole, C. L. (2000). Building Loyalty. Workforce, Vol. 79, pp. 42-47. Available EBSCO host full display.

Collins, C. J. and Clark, K. D. (2003). Strategic human resource practices, top management commitment, team social networks and firm performance: the role of human resource practices in creating organizational competitive advantage. Acad. Manage., 46(6): 740-751.

Connaissance. Rapport pour la Commission Europe enne, Brussels.

Cromwell, S. E. and Kolb, J. A. (2004). An Examination of Work-Environment Support Factors Affecting Transfer of Supervisory Skills Training to the Workplace, H. Res. Dev. Q., 15(4): 449-471.

Cropanzano, R., Byrne, Z. S., Bobocel, D. R., and Rupp, D. E. (2001). Moral virtues, fairness heuristics, social entities, and other denizens of organizational justice. Journal of Vocational Behavior, 58: 164-209.

Daniels, A. (1999). Bringing out the Best in People: How to Apply the Astonishing Power of Positive Reinforcement (2nd ed.). NewYork: McGraw-Hill.

Darling, K., Arm, J., and Gatlin, R. (1997). “How to effectively reward employees”. Industrial Management, Vol. 39, No. 4, pp. 1-4.

Davies, R. (2001). How to boost staff retention in people management, 7(8): 54-56.

Davy, J., Kinicki, A., and Scheck, C. (1991). Developing and Testing a Model of Survivor Responses to Layoffs. Journal of Vocational Behaviour, Vol. 38, pp. 302-317.

De la Fuente, A. and Ciccone, A. (2002). Le capital humain dans une e 'conomie mondiale sur la.

DeCenzo, D. A. and Robbins S. P. (2010). Fundamentals of Human Resource Management (10th ed.), Hoboken, NJ: John Wiley \&Sons, Inc.

Deckop, J. R., Konard, A. M., Perlmutter, F. D., and Freely, J. L. (2006). The effect of human resource management practices on the job retention of former welfare clients. Hum. Resource. Manage, 45(4): 539-559.

Delaney, J. and Huselid, M. (1996). The Impact of HRM Practices on Perception of Organizational Performance. Academy of Management Journal, Vol. 39, pp. 949-969.

Delery, J. E. and Doty, D. H. (1996). Modes of theorizing in strategic human resource management: tests of universalistic, contingency and configurational performance predictions. Acad. Manage. J., 39(4): 802-835.

Deming, W. E. (1982). Quality, Productivity and Competitive Position, MIT Center for Advanced Engineering, Cambridge, MA.

Demski, J. and Feltham, G. (1978). Economic Incentives in Budgetary Control Systems. The Educational Theory, 57(2), 159-170.

Denison, E. F. (1962). The Sources of Economic Growth in the United States and the Alternatives before Us. NY: Committee for Economic Development. 
Denton, J. (2000). Using Web-based projects in a Systems Design and Development Course. Journal of Computer Information Systems, Vol. 40, No. 3, pp. 85-87.

Doyle, M. (1997). Management development, in Beardwell, I. and Holden, L. eds Human Resource Management: A Contemporary Perspective, London: Pitman.

Drobnic, S., Behan, B., and Prag, P. (2010). Good job, good life? Working conditions and quality of life in Europe. Social Indicators Research, 99(2), 205-225.

Earle, H. A. (2003). Building a workplace of choice: Using the work environment to attract and retention. Journal of Facilities Management, 2(3), 244-257.

Edvardsson, B. O. and Gustavsson, B. (2003). Quality in the work environment: A prerequisite for success in new service development. Manage. Ser. Qual., 13(2): 148-163.

Ensor, J., Pirrie, A., and C. Band. (2006). Creativity work environment: do UK advertising agencies have one? Eur J. Innov. Manage., 9(3): 258-268.

Fitz-enz, J. (1990). Getting and Keeping Good Employees. Personnel Journal, Vol. 67, No. 8, pp. 25-29.

Fitzsimons, P. (1999). "Human Capital Theory and Education”. The Encyclopedia of Education. London: Macmillan. Flexibility, supportive work-life policies, and use of formal flexible arrangements and occasional flexibility to employee engagement and expected retention, 11(2): 183-197.

Fombrun, C. (1996), Reputation. Realizing Value from the Corporate Image, Harvard Business School Press, Boston, MA.

Frank, R. H. and Bernanke, B. S. (2007). Principles of Microeconomics (3rd ed.). New York: McGraw-Hill/Irwin.

Freyer, M. (2007). Retaining Employees in a Tightening Labor Market, RSM McGladrey.

Garavan, T. N., Morley, M., Gunnigle, P., and Collins, E. (2001). Human Capital accumulation: The role of human resource development. Journal of European Industrial Training, 25(2/3/4), 48-68.

Gberebie, D. E. (2008). Staff Recruitment, Retention Strategies and Performance of Selected Public and Private Organizations in Nigeria, Ph.D. Thesis, Coll.Bus.Soc.Sci., CovenantUni., Ota.

Gentry, W. A., Kuhnert, K.W, Mondore, S. P, and Erin, E. P. (2007). The influence of supervisory-support climate and unemployment rate on part-time employee retention a multilevel analysis. J. Manage. Dev., 26(10): 1005-1022.

Ginsberg, L. (1997). “Training for the long haul”. Computer Shopper, Vol. 17, p. 4.

Gold, M. (2001). Breaking all the rules for recruitment and retention. Journal of Career Planning and Employment, 61(3): 6-8.

Gostick, A. and Elton C. (2007). The Daily Carrot Principle: 365 Ways to Enhance Your Career and Life. New York: Simon \& Schuster.

Govindarajulu, N. D. and Bonnie, F. (2004). Motivating employees for environmental improvement. Ind. Manage. Data Syst., 104(4): 364-372.

Gronroos, C. (1984). “A service quality model and its marketing implications”. European Journal of Marketing, Vol. 18, pp. 36-44.

Gronroos, C. (1990). "Relationship approach to marketing in service contexts: The marketing and organisational behaviour interface”. Journal of Business Research, Vol. 20, No. 1, pp. 3-11.

Gronroos, C. (1992). Service Management: a Management Focus for Service Competition. in Lovelock, C. H. Managing Services: Marketing, Operations and Human Resources. 2nd ed., Prentice-Hall, Englewood Cliffs, NJ, pp. 9-16.

Grubb, W. N. and Lazerzon, M. (2004). The Education Gospel: The Economic Power of Schooling. MA: Harvard University Press.

Gummesson, E. and Grönroos, C. (1988). “Quality of services: lessons from the product sector”. In Surprenant, C. (Ed.), Add Value to Your Service, American Marketing Association, Chicago, IL.

Gutteridge, T. G., Leibowitz, Z. B., and Shore, J. E. (1993). When Careers Flower, Organizations Flourish. Train. Dev. J., 47: 24-29.

Hackman, J. R. and Oldham, G. R. (1976). “Motivation through design or work”. Organizational.

Hackman, J. R. and Oldham, G. R. (1980). Work redesign, Redesigns. M.A: Addison-Wesley.

Haile, G. (2009). Workplace Job Satisfaction in Britain: Evidence from Linked Employer-Employee Data. Discussion 
Paper Series, Forschungsinstitut zur Zukunft der Arbei Institute for the Study of Labor.

Hair, J. F., Black, W. C., Babin, B. J., Anderson, R. E., and Tatham, R. L. (2006). Multivariate data analysis (6th ed.). New Jersey: Pearson Prentice Hall.

Halbesleben, L. R. B. and Wheeler, A. R. (2008). The relative roles of engagement and embeddedness in predicting job performance and intention to leave. Work and Stress, 22, 242-256.

Harbison, F. H. (1962). "Human Resources Development Planning in Modernizing Economies”. International Labor Review, 453-458

Hassan, M., Hassan, S., Khan, K. U., and M. Akram Naseem. (2011). Employee Retention as a Challenge in Leather Industry. Global Journal of Human Social Science, Vol. 11, No. 2, Version 1.0.

Hatch, M. J., Schultz, M., and Williamson, J. (2003). "Bringing the corporation into corporate branding”. European Journal of Marketing, Vol. 37, No. 7/8, pp. 1041-64.

Hayday, S. (2003). "Staff commitment is the key to an improved performance.” Personnel today.

Herzberg, F. (1966). Work and the nature of man. Cleveland: world.

Herzberg, F., Mausner, B., and Syderman, B. (1959). The motivation to work. New York: Wiley.

High House, S., Stierwalt, S. L., Bachiochi, P., Elder, A. E., and Fisher, G. (1999). Effects of Hill Book Company. Hill.

Ho, J. L. Y., Wu, A., and Lee, L. C. (2009). How Changes in Compensation Plans Affect Employee Performance, Recruitment, and Retention: An Empirical Study of a Car Dealership. Contemporary Accounting Research, Vol. 26, No. 1, pp. 167-199.

Huselid, M. A. (1995). "The impact of human resource management practices on turnover, productivity and corporate financial performance”, Acad. Manag. J., 38(3): 635-72.

Hytter, A. (2008). Dark Side Leaders, Work Environment and Employee Health.

Iaffaldano, M. T. and Muchinsky, P. M. (1985). “Job satisfaction and job performance: A meta-analysis”. Psychological Bulletin, 97(2), 251-273.

Ichniowski, C., Shaw, K., and Prennushi, G. (1997). The effect of human resource management practices on productivity. American Economic Review, 87: 291-313.

Johnson, M. (2000). Winning the People War, Talent and the Battle for Human Capital. Financial Times Management.

Kandampully, J. and Hu, H. H. (2007). “Do hoteliers need to manage image to retain loyal customers?”, International Journal of Contemporary Hospitality Management, Vol. 19, No. 6, pp. 435-443.

Keller, J. M. (1999). "Motivational systems”, in: H. D. Stolovitch \& E. J. Keeps (Eds.), Handbook of Human Performance Technology (2nd ed.), San Francisco: Jossey-Bass/Pfeiffer, pp. 373-394.

Kossivi, B., Xu, M., and Kalgora, B. (2016). Study on determining factors of employee retention. Open Journal of Social Sciences, 4, 261-268.

Kouzes, J. M. and Posner, B. Z. (2003). The Leadership Challenge. San Francisco: Jossey-Bass.

Kreitner, R. and Kinicki, A. (1998). Organizational behavior. (4th ed.) Boston: Irwin McGraw.

Lee, T. W., Mitchell, T. R., Holtom, B. C., Sablynski, 1. P., and Burton, 1. P. (2004). The effects of job embeddedness on organizational citizenship, job performance, volitional absences, and voluntary turnover. Academy of Management Journal, 47, 711-722.

Levi, L. (2002, September 19-20). Special Issue Stress at Work the European Commission's Guidance on work-related stress: from words to action. TUTB Newsletter, pp. 12-17.

Little, A. B. and Little, D. W. (2009). "The home team approach to service quality: linking and leveraging communication between human resources, operations and marketing”. Journal of Organisational Culture, Communication and Conflict, Vol. 13, No. 2, pp. 57-70.

MacDuffie, J. (1995). Human Resource Bundles and Manufacturing Performance: Organizational Logic and Flexible Production System in the World Auto Industry. Industrial and Labour Relations Review, Vol. 48, pp. 197-221.

Maconachie, R. and Hilson, G. (2011). Safeguarding livelihood or exacerbating poverty? Artisanal mining and formalization in West Africa. Natural Resources Forum, 35(2011): 293-303.

Maertz, C. P. and Campion, M. A. (1998). 25 Years of Voluntary Turnover Research: A Review and Critique. Interna- 
tional Review of Industrial and Organizational Psychology, Vol. 13, pp. 49-81.

March, J. G. and Simon, H. A. (1958). Organizations. New York: John Wiley and Sons.

Martin, T. N. (1979). “A Contextual Model of Employee Turnover Intentions”. Academy of Management Journal, 22(2), 313-324.

Mels, G., Boshoff, C., and Nel, D. (1997). "The dimensions of service quality: The original European perspective revisited.” The Service Industries Journal, Vol. 17, pp. 173-189.

Mercer, R. (2003). Mercer study raises red flags for employer pay and benefits plans (findings of the 2002 people at work survey). In human resource department management report. Pp. 8-15.

Meyer, J. P. and Allen, N. J. (1991). A Three Component Conceptualization of Organizational Commitment. Human Resource Management Review, Vol. 1, pp. 89-93.

Michie, L. and Sheehan-quinn, M. (2001). Labour market flexibility, human resource management and corporate performance. Brit. J. Manag., 12(4): 287-306.

Michie, J. and Sheehan-Quinn, M. (2001). Labour Market Flexibility, Human Resource Management and Corporate Performance. Brit. J. Manage., 12(4): 287-306.

Milkovich, G. M. and Newman, J. M. (2004). Compensation (8th ed.) Burr. Ridge, IL. Irwin McGraw-Hill.

Miller, D. (2006). Strategic human resource management in department stores: An historical perspective. J. Retailing and Consum. Serv., forthcoming.

Miller, N., Erickson, A., and Yust, B. (2001). "Sense of place in the workplace: The relationship between personal objects and job satisfaction and motivation.” Journal of Interior Design, 27(1), 35-44

Mills, J. and Clark, M. S. (1982). Exchange and communal relationships. Review of Personality and Social Psychology, 3: 121-144.

Milman, A. (2003). "Hourly employee retention in small and medium attractions: the central Florida example”. Int.l J. Hospitalit. Manage, 22(2): 17-35.

Milman, A. and Ricci, P. (2004). "Predicting job retention of hourly employees in the lodging industry". Journal of Hospitality and Tourism.

Mitchell, T. R., Holtom, B. C., Lee, T. W., Sablynski, C. L., and Erez, M. (2001). Why people stay: Using job embeddedness to predict voluntary turnover. The Academy of Management Journal, 44, 1102-1121.

Moncraz, E., Zhao, J., and Kay, C. (2009). An Exploratory Study of US Lodging Properties' Organizational Practices on Employee Turnover and Retention. International Journal of Contemporary Hospitality Management, Vol. 21, No. 4, pp. 437-458.

Morrell, K. M., Clarke J. L., and Wilkinson, A. J. (2004). Organizational Change and Employee Turnover. Personnel Review, Vol. 33, No. 2, pp. 161-166.

Muhammad, I. (2011). Factors Affecting Employees Retention: Evidence from Literature. Abasyn Journal of Social Sciences, Vol. 4, No. 2.

Nanjundeswaraswamy, T. S. and Swamy, D. R. (2013). Review of quality of work life. International journal for quality research, 7(2), 201-214.

Nelson, B. (2004). "Everything you thought you knew about recognition is wrong”, Workforce Management, available online at: http://www.workforce.com.

Nelson, B. (2005). 1001 Ways to Reward Employees (2nd ed.). New York: Workman Publishing.

Nelson, B. and Spitzer, D. R. (2003). The 1001 Rewards \& Recognition Field Book: The Complete Guide. New York: Workman Publishing Company.

Ngo, H., Turban, D., Lau, C., and Lui, S. (1998). Human resource practices and firm performance of multinational corporations: influences of country origin. Int. J. Human Res. Manage., 9(4): 632-652.

Nguyen, N. (2006). "The collective impact of service workers and servicescape on the corporate image formation". International Journal of Hospitality Management, Vol. 25, No. 2, pp. 227-44.

Normann, R. (1986). Service Management. Strategy and Leadership in Service Business. Chichester: Wiley.

Odusola, A. F. (1998). "Human Investment and the Empirics of Economic Growth”. Selected Papers for the NES Annual Conference, Ibadan. 
Olowu, D. and Adamolekun, L. (2005). Human Resource Management, Public Administration in Africa: Main Issues and Selected Country Studies. Ibadan: Sprectrum Books.

Olusegun, O. T. and Adenugba, A. A. (2013). "Human Capital Development in First Bank of Nigeria PLC”. Mediterranean Journal of Social Sciences, 4(2), 783-801.

Oluwatobi, S. O. and Ogunrinola, I. O. (2011). “Government Expenditure on Human Capital Development: Implications for Economic Growth in Nigeria”. Journal of Sustainable Development, 4(3), 72-80

Opoku, R. A., Yiadom, N. A., Chong, C. S., and Abratt, R. (2008). "The impact of internal marketing on the perception of se5rvice quality in retail banking: A Ghanaian case”. Journal of financial Services Marketing, Vol. 13, No. 4, pp. 317-329.

Organ, D. W. (1988). Organizational citizenship behavior: The good soldier syndrome. Lexington, MA: Lexington Books.

Organ, D. W. (1990). The motivational basis of organizational citizenship behavior. Research in Organizational Behavior, 12: 43-72.

Organ, D. W. and Konovsky, M. (1989). Cognitive versus affective determinants of organizational citizenship behavior. Journal of Applied Psychology, 74: 157-164.

Park, H. Y., Ofori-Dankwa, J., and Bishop, D. R. (1994). Organizational and environmental determinants of functional and dysfunctional turnover: practical and research implications. Human Relations, 47(3): 353-66.

Partlow, C. G. (1996). "Human-resources practices of TQM hotels”, Cornell Hotel \& Restaurant Administration Quarterly, Vol. 37, No. 5, pp. 67-77.

Paul, A. K. and Anantharaman, R. N. (2003). Impact of people management practices on organizational performance: analysis of a causal model. Int. J. Human Res. Manage., 14(7): 1246-1266.

Perrin, T. (2003). Rewards: the not-so-secret ingredient for managing talent. (Retention). HR focus, 80(1): 3-10.

Pfeffer, J. (1998). Six myths about pay. Harvard Business Review, May-June, 38-57.

Probst, T. M. (2002). The impact of job security on employee work attitudes, job adoption, and organizational withdrawal behaviours. In J. M. Brett and F. Drasgow (Eds.), The psychology of work: Theoriticallly based empirical research. Mahwah, NJ: Lawrence Eribaum Associates.

Psacharopoulos, G. and Woodhall, M. (1997). Education for Development: An Analysis of Investment Choice. New York: Oxford University Press.

Ramlall, S. (2003). Managing employee retention as a strategy for increasing organizational competitiveness. Applied HR.M Research, 8, 63-72.

Ramlall, S. (2003). Managing Employee Retention as A Strategy For Increasing Organizational Competitiveness. Applied H.R.M. Research, 8(2), 63-72.

Ramlall, S. (2003). Organizational Application Managing Employee Retention as a Strategy for Increasing Organizational Competitiveness. Applied H.R.M. Research, 8(2), 63-72.

Rastogi, P. N. (2002). Knowledge Management and Intellectual Capital as a Paradigm of Value Creation. Human Systems Management. 21(4). 229-240.

Rathi, N. and Rastogi, R. (2008). "Job satisfaction and psychological well-being”, The ICFAI Journal of Organizational Behavior, Vol. 7, No. 4, pp. 47-57.

Richman, A., Civian, J., Shannon, L., Hill, J., and Brennan, R. (2008). The relationship of perceived.

Robbins, S. and Judge, T. (2008). Organizational Behavior (12th ed.). New Jersey: Prentice Hall, Inc.

Robbins, S. P. (1993). Organizational behaviour. (6th ed.). Englewood cliffs: Prentice-hall.

Rodriguez, P. J. and Loomis, R. S. (2007). A New View of Institutions, Human Capital, and Market.

Romer, P. M. (1990). Endogenous Technological Change. Journal of Political Economy, 98(5), 71-102.

Rosen, H. S. (1999). Public Finance. New York: McGraw-Hill.

Ruvio, A. and Rosenblatt, Z. (1996). Job Insecurity among Israeli School Teachers: Sectorial Profiles and Organizational Implications. Journal of Educational Administration, pp. 521-539.

Salop, J. and Salop, S. (1976). Self-selection and Turnover in the Labor Market. Quarterly Journal of Economics, Vol. 
90, No. 4, pp. 619-627.

Sapovadia, V. and Sweta, P. (2013). Business Ethics \& Employee Turnover: CAFE Matrix. International Journal for Research in Management and Pharmacy, Vol. 2, No. 4.

Sarstedt, M., Wilczynski, P., and Melewar, T. C. (2012). "Measuring reputation in global markets-A comparison of reputation measures' convergent and criterion validities”. Journal of World Business, under press, pp. 1-11.

Sartain, L. and Finney, M. I. (2003). HR from the Heart: Inspiring Stories and Strategies for Building the People Side of Great Business. New York: AMACOM.

Scheffer, J. (2002). Dealing with missing data. Research Letters in the Information and Mathematical Sciences, 3(1), 153-160.

Schultz, T. W. (1961). Investment in human capital. The American Economic Review, 51(1), 1-17.

Schultz, T. W. (1971). Investment in Human Capital. New York: Free Press.

Sen, A. (1999). Development as Freedom. New York: Anchor Books.

Severinsson, E. and Hummelvoll, J. K. (2001). "Factors influencing job satisfaction and ethical dilemmas in acute psychiatric care”. Nursing and Health Sciences, Vol. 3, No. 2, pp. 81-90.

Sharma, J. L. (1998). A textbook of construction management and account ( $3^{\text {rd }}$ edition).

Shaw, J., Delery, J., Jenkins, G. J., and Gupta, N. (1998). “An organization-level analysis of voluntary and involuntary turnover”. Acad. Manage. J., 41(5): 511-26.

Shaw, L. D., Delery, L. E., Jenkins, G. D., and Gupta, N. (1998). An organization-level analysis of voluntary and involuntary turnover. The Academy of Management Journal, 41, 511-525.

Sheffrin, M. S. (2003). Economics: Principles in Action. New Jersey: Pearson Prentice Hall.

Shoaibu, M., Noor, A., Tirmizi, S. R., and Bashir, S. (2009). Determinants of Employee Retention in Telecom Sector of Pakistan, Proceedings 2nd CBRC, Lahore, Pakistan. Management practices on productivity: A study of steel finishing lines”. The American Management, 11(1):23-41. Management Practices on Operational Performance: Recognizing Country and Industry.

Shore, L. M., Tetrick, L. E., and Barksdale, K. (1999). Measurement of transactional and exchange relationships. Paper presented at the annual meeting of the Society for Industrial and Organizational Psychology, Atlanta, GA.

Shore, L. M., Tetrick, L. E., Taylor, M. S., Coyle-Shapiro, J., Liden, R. C., McLean-Parks, J., et al. (2004). The employee-organization relationship: A timely concept in a period of transition. In J. J. Martocchio (Ed.), Research in personnel and human resources management, Vol. 23: 291-370. Amsterdam: Elsevier.

Sidorkin, M. A. (2007). Human Capital and the Labor of Learning: A Case of Mistaken Identity.

Silbert, L. T. (2005). The effect of Tangible Rewards on Perceived Organizational Support. Management Sciences. Website: uwspace.uwaterloo.ca/bitstream/10012/872/1/lsilbert2005.pdf.

Sjöberg, A. and Sverke, M. (2000). "The interactive effect of job involvement and organizational commitment on job turnover revisited: A note on the mediating role of turnover intention".

Slatten, T. (2008). “Antecedents and effects of emotional satisfaction on employee-perceived service quality.” Managing Service Quality, Vol. 18, No. 4, pp. 370-386.

Smith, M. K. (2001). "Young people, informal education and association", The informal education homepage, www.infed.org/youthwork/ypandassoc.htm. Last updated: December 2001.

Snell, S. and Dean, J. (1992). Integrated Manufacturing and Human Resource Management: A Human Capital Perspective. Academy of Management Journal, Vol. 35, pp. 467-504.

Snell, S. and Youndt, M. (1995). Human Resource Management and Firm Performance. Journal of Management, Vol. 21, No. 71, pp. 1-738.

Solent, D. (2006). "Introducing employee social identification to customer satisfaction research: a hotel industry study". Managing Service Quality, Vol. 16, No. 6, pp. 575-594.

Solomon, C. M. (1992). The Loyalty Factor. Personnel Journal, Vol. 52, pp. 32-37.

Standardization. Education, Knowledge \& Economy, 1(1), 93-105.

Steers, R. and Porter, L. (1983). Motivation \& work behavior (3rd ed.). New York: McGraw.

Stiglitz, J. (1975). Incentives, Risk, and Information: Notes toward a Theory of Hierarchy. Bell Journal of Economics, 
Vol. 6, No. 2, pp. 552-579.

Surprenant, C. F. and Solomon, M. R. (1987). "Predictability and personalization in the service encounter”. Journal of Marketing, Vol. 51, April, pp. 86-96.

Taplin, I. M., Winterton, J., and Winterton, R. (2003). Understanding Labour Turnover in a Labour Intensive Industry: Evidence from British Clothing Industry. Journal of Management Studies, Vol. 40, No. 4, pp. 1021-1046.

Trevor, C. O., Barry, G., and Boudreau, J. W. (1997). "Voluntary turnover and job performance: Curvilinearity and the moderating influences of salary growth and promotions”. J. Appl. Psychol., 82(1): 44-61.

University of Iowa. (2009). "Reward \& recognition”, available online at: http://research.uiowa.edu/pimgr/?get=reward.

US Department of Labour. (1993). High Performance Work Practices and Firm Performance, Government Printing Office, Washington, DC.

Växjö University, Studies in Leadership, Entrepreneurship, and Organization Website: hvxu.se/ehv/forskning/hofres eminarier/2008/080514\%20DarkSide\%20Final\%20version.pdf.

Walker, J. W. (2001). “Perspectives”. Human Resource Planning, 24(1): 6-10.

Walsh, K. and Taylor, M. (2007). Developing in-house careers and retaining management talent. Cornell Hotel and Restaurant Administration Quarterly, 48(2): 163-82. Website: www.cfo.com/whitepapers/index.cfm/displaywhitepaper/ 10308654?topicid=10240327 - 22k -.

Watson, I., Buchanan, J., Campbell, I., and Briggs, C. (2003). Fragmented Futures: New Challenges in Working Life. Sydney. New South Wales: The Federation Press.

Wayne, S. J., Shore, L. M., and Liden, R. C. (1997). Perceived organizational support and leader-member exchange: A social exchange perspective. Academy of Management Journal, 40, 82-111.

Wells, M. and Thelen, L. (2002). "What does your workspace say about you? The influence of personality, status and workspace on personalization.” Environment and Behavior, 3: 300-321.

Williams, M. and Dreher, G. (1992). Compensation systems attributes and applicant pool characteristics. Academy of Management Journal, 435: 571-95.

Willis, C. (2000). Go for your goals. Working woman. Pp. 6-7.

Wyatt, W. (1999). Work USA 2000: Employee commitment and the bottom line. Bethesda, MD: Watson Wyatt. Pp. 43-58.

Youndt, M., Snell, S., Dean, J. J., and Lepak, D. (1996). "Human resource management, manufacturing strategy, and firm performance”. Acad. Manage. J., 39(4): 836-66.

Youndt, M., Snell, S., Dean, J. J., and Lepak, D. (2004). Intellectual Capital Profiles: An Examination of Investments and Returns. Journal of Management Studies, 41(2), 335-361.

Zeithaml, V. A., Parasuraman, A., and Berry, L. L. (1990). Delivering Quality Service. The Free Press, New York, NY.

Zeytinoglu, I. U. and Denton, M. (2005). Satisfied workers, Retained Workers: Effects of work and work environment on Homecare workers' Job satisfaction, Stress, Physical Health, and Retention. (CHSRF FCRSS: Candanian Health Services Research Foundation, Foundation canadienne de la recherché sur les services de sante ${ }^{e c}$ ).

Zhu, Y. (2004). Responding to the challenges of globalization: human resource development in Japan. J. World Bus., 39: 337-348. 


\section{Appendix A1: Questionnaire}

School of Postgraduate Studies.

Department of Business Administration

Faculty of Management Sciences,

University of Jos,

P.M.B 2084,

Jos,

Plateau State.

Dear Respondent,

I am an MSc student conducting a study on the impact of Human Resource Development on Employee Retention in some selected banks in Bauchi. In order to accomplish this study, I am seeking your co-operation to respond to the following questions. Information provided will be treated with utmost confidentiality. There is no right or wrong answers.

Thank you for making this study a success.

\section{Section A}

\section{Background Information (Please Fill In/Select What Applies To You)}

A1. Name of Organization

A2. Department/Section

A3. Rank

A4. Educational Qualification

A5. Age

(2) 26 - 35Years

(3) 36 - 45Years

(4) $>45$ years

A6. Gender: (1) Male

(2) Female

A7. Marital Status: (1) Single

(2) Married

(3) Widowed

(4) Divorced

\section{Section B: Learning Opportunity}

Here are some indicators of learning opportunity. Kindly tick your opinion as it applies to where you work.

\begin{tabular}{|c|c|c|c|c|c|c|}
\hline \multicolumn{2}{|r|}{ Statement } & \multirow{2}{*}{$\begin{array}{c}\begin{array}{r}\text { Strongly } \\
\text { disagree }\end{array} \\
1\end{array}$} & \multirow{2}{*}{$\begin{array}{c}\text { Disagree } \\
2\end{array}$} & \multirow{2}{*}{$\begin{array}{c}\text { Undecided } \\
3\end{array}$} & \multirow{2}{*}{$\begin{array}{c}\text { Agree } \\
4\end{array}$} & \multirow{2}{*}{$\begin{array}{c}\begin{array}{c}\text { Strongly } \\
\text { agree }\end{array} \\
5\end{array}$} \\
\hline LO1 & $\begin{array}{l}\text { If learning opportunities are given to employ- } \\
\text { ees, they will, likely, be retained. }\end{array}$ & & & & & \\
\hline LO2 & $\begin{array}{l}\text { Employees eventually lose interest in a compa- } \\
\text { ny when there is no opportunity for academic or } \\
\text { learning development. }\end{array}$ & 1 & 2 & 3 & 4 & 5 \\
\hline LO3 & $\begin{array}{l}\text { Learning opportunity increases productivity and } \\
\text { guarantees retention. }\end{array}$ & 1 & 2 & 3 & 4 & 5 \\
\hline LO4 & $\begin{array}{l}\text { Company do not give learning opportunity to } \\
\text { employees for fear that employees may desire } \\
\text { to resign after obtaining much know-how. }\end{array}$ & 1 & 2 & 3 & 4 & 5 \\
\hline LO5 & $\begin{array}{l}\text { Study-without-pay policy promotes employee } \\
\text { retention. }\end{array}$ & 1 & 2 & 3 & 4 & 5 \\
\hline
\end{tabular}




\section{Section C: Employee Retention}

Here are some indicators of employee retention. Kindly tick your opinion as it applies to where you work.

\begin{tabular}{|c|c|c|c|c|c|c|}
\hline \multicolumn{2}{|r|}{ Statement } & $\begin{array}{l}\text { Strongly } \\
\text { disagree }\end{array}$ & Disagree & Undecided & Agree & $\begin{array}{c}\text { Strongly } \\
\text { agree }\end{array}$ \\
\hline ET1 & $\begin{array}{l}\text { I am still working for this organization because I don’t } \\
\text { have option to turn to for now. }\end{array}$ & 1 & 2 & 3 & 4 & 5 \\
\hline ET2 & $\begin{array}{l}\text { I feel there is better opportunity for me to move to a } \\
\text { better Banking job. }\end{array}$ & 1 & 2 & 3 & 4 & 5 \\
\hline ET3 & $\begin{array}{c}\text { Moving to another banking job will give me more } \\
\text { benefit. }\end{array}$ & 1 & 2 & 3 & 4 & 5 \\
\hline ET4 & $\begin{array}{c}\text { The rate of employee retention in my organization is } \\
\text { higher than others. }\end{array}$ & 1 & 2 & 3 & 4 & 5 \\
\hline ET5 & $\begin{array}{c}\text { My organization is not bothered with the rate at which } \\
\text { the Bankers quit. }\end{array}$ & 1 & 2 & 3 & 4 & 5 \\
\hline
\end{tabular}

